\title{
USÛLÜ'L-İFTÂ VE ÂDÂBUHÛ, MUHAMMED TAKÎ EL-OSMÂNî
}

Ușūl al-iftā' wa-ādābuhu, Muḥammad Taqī 'Ușmānī

\section{Ünal ŞAHIIN}

Arş. Gör., Artvin Çoruh Üniversitesi, İlahiyat Fakültesi, Temel İslam Bilimleri Bölümü, İslam Hukuku Anabilim Dalı, Artvin, Türkiye

Res. Assist., Artvin Coruh University Faculty of Theology Department of Basic Islamic

Education Department of Islamic Law, Artvin, Turkey

unalsahinn29@gmail.com | https://orcid.org/0000-0001-6741-4943

(i) Makale Bilgisi / Article Information:

Makale Türü / Article Type: Kitap Tanıtımı / Book Review

Geliş Tarihi / Received: 04.11.2020

Kabul Tarihi / Accepted: 05.12.2020

Yayın Tarihi / Published: 31.12.2020

g Atıf / Cite as: Şahin, Ünal. "Usûlü'l-iftâ ve âdâbuhû, Muhammed Takî el-Osmânî”. Mütefekkir 7/14 (2020), 635-640. https://doi.org/10.30523/mutefekkir.849997

(C) Telif / Copyright: Published by Aksaray Üniversitesi İslami İlimler Fakültesi / Aksaray University Faculty of Islamic Education, 68100, Aksaray, Turkey. Tüm Hakları saklıdır / All rights reserved.

İntihal / Plagiarism: Bu çalışma hakem değerlendirmesinden geçmiş, bir intihal yazılımı ile taranmıştır. İntihal yapılmadığı tespit edilmiştir. This article has gone through a peer review process and scanned via a plagiarism software. No plagiarism has been detected. 


\section{USÛLÜ'L-İFTÂ VE ÂDÂBUHÛ, MUHAMMED TAKÎ EL-OSMÂNî ${ }^{*}$}

Usulü'l-iftâ eserleri genel olarak müftünün fetva verirken, müsteftînin ise fetva isterken uyması gereken kurallar bütününe dair kaleme alınan eserlerdir. Takiyyüddin el-Osmânî'nin Usulü'l-iftâ ve âdâbuhû isimli eseri de bu literatürün son dönem örnekleri arasındadır. Eser, müellifin üniversitede ders verirken hazırladığı ders notlarının bir araya getirilmesiyle oluşmuştur.

Fetvanın lügavî ve istılahî anlamlarına değinen Osmânî, fetvayı şer'î, fikhî ve cüzî̀ olmak üzere üç kısımda incelemiştir. Serî́fetva, Hz. Peygamber döneminde ortaya çlkan bir olay veya sorulan soru karşısında Kitap veya Sünnet'le sabit olan hükümler olarak tavsif edilmekte ve ilgili

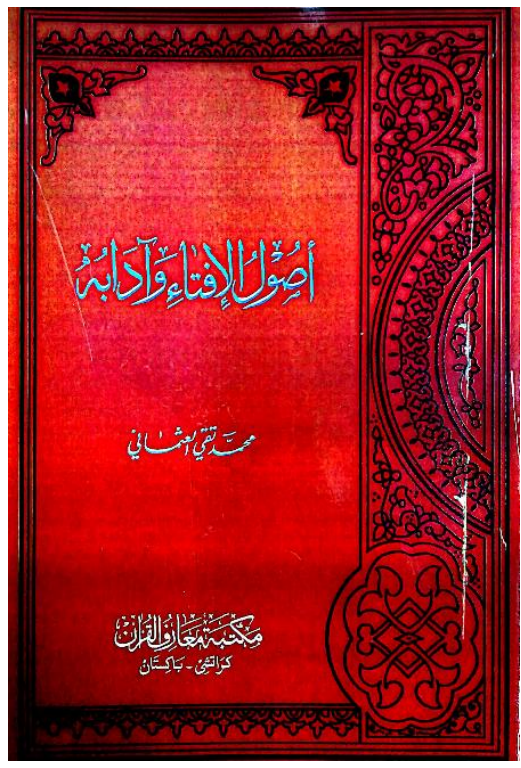
âyet ve hadisler örnek olarak verilmektedir. Flkhîfetva, fakihin füru fıkıhtaki mesâili detaylandırırken ulaşmış olduğu hükümdür. Cüz'̂̂ fetva ise muayyen bir olay karşısında sorulan sorunun küllî olan fikhın cüz'î bir konuma indirilerek cevaplanmasıdır.

Fetva ve kazâ arasındaki farka değinen Osmânî, kazânın, müsteftî için bağlayıcılığına, hâkimin müftüden farklı olarak delil talebine olayı araştırma yetkisine, kazâda akidevî bahisler ve ibadetlerle ilgili konuların yer almamasına işaret eder.

Selef ulemanın liyakatli olmalarına rağmen fetva vermekten ne kadar uzak durduklarına dikkat çeken Osmânî, bununla ilgili nakillere yer vermiştir. Hz. Peygamber ve sahabe döneminde fetvaya değinen müellif, özellikle sahabenin fetvada önde gelen isimlerini ve sahabenin fetvalarını toplayan son dönem çalışmalarını zikreder (s. 35-36). Tabiînin fakihlerini ikiye ayıran Osmânî, tabiînin büyük kısmının hadis rivayetiyle meşgul olduğunu, diğerlerinin ise fıkıh ve fetvayla ilgilendiğini söyler. Nevâzil fıkhı olarak nitelendirilen, meydana gelmeyen, şeylerden soru sorulmasının özellikle yukarıda belirtilen birinci grup tarafından hoş karşılanmadığı ve seleften bu yönlü yasaklayıcı nakillere yer verilmiştir.

Ehl-i hadis ve ehl-i re’y ayrımına değinen müellif, bu kısımda özellikle iki grup için yaygın olan birkaç yanılgıya işaret etmektedir. Bunlardan ilki,

* Muhammed Takî el-Osmânî, Usulü'l-iftâ ve âdâbuhû.(Pakistan: Mektebetü Maârifi'l-Kur'ân, 2011). 
ehl-i hadisin kıyası hüccet kabul etmedikleri, ehl-i re'yin ise nas bulunsa dahi re'yi mevcut nas üzerine takdim ettiği ön kabulüdür. İkincisi, re'yin "mücerred akla dayanan şahsi fikirlerden ibaret" olduğu algısının yanlışlığıdır. Üçüncü olarak müellif, 'ehl-i re'yin' sadece Hanefîlere tesmiyesi anlayışının yanlış olduğunu söylemektedir. Zira bu lakabın Mâlikîler için de kullanıldığı hatta mezhepteki otorite isimlerden olan İbn Abdilber'in eserinin adının elİstizkâr limâ tezammenehu el-Muvatta min me'âni'r-re'y ve'l-âsâr olmasina dikkat çekmiştir. Ancak Hanefîlerin cüz'î meseleleri tefri' etmeleri ve mezhebin bazı görüşlerinin hadise muhalif olarak gözükmesi, insanları Hanefî mezhebini bu isimle anmaya daha çok sevk ettiğini belirtmiştir (s. 58).

Taklid ve bir mezhebi benimseme hususuna değinen Osmânî'nin bir mezhebe tâbi olma ve onunla amel etmedeki vurgusu dikkat çekicidir. Sahabe döneminde yaşayanlar için fetva veren kimselerden tercihte bulunarak, bunlardan birisinin fetvasının tercih edilmesinin o dönem için meşru olduğu ancak dört mezhebin oluşumundan sonra böyle bir seçeneğin herhangi bir kimseye verilmesinin 'hevaya tâbi olmak' olacağını belirtmektedir (s. 63). Telfik anlayışına karşı olduğu anlaşılan müellif, 'telfikin sıhhatine kimsenin cevaz vermediğine', ayrıca telfikin toplumu kaosa götüreceğine işaret etmiş$\operatorname{tir}$ (s. 64).

Müellif bu noktada selef ulemadan nakillerde bulunmuştur. Bağlamında uzunca yer alan bu nakillerin ortak vurgusu, muayyen bir mezhebin taklit edilmesinin gerekliliği, tek bir mezhebin taklit edilmemesinin mezhepler arası tercihlere götüreceği bunun ise hevaya tâbi olmak olduğu, ayrıca taklidin toplumsal düzeni sağlayacağı şeklinde ifade edilebilir.

Osmânî, konunun sonunda taklitle alakalı dörtlü tasnifine yer vermektedir. Illk kısım, avâmın taklididir. Bu grup içerisinde Kur'an ve Sünnet'te herhangi bir bilgisi olmayan, medrese veya ilahiyat fakültelerinden mezun olan kimselerin yer aldığını belirtmektedir. İkinci kısım, küllî içtihat derecesine ulaşmamış ancak alanında uzman kimselerin taklididir. Bu kimselerin uzun zaman fikıhla ve fetvayla iştiğal etmeleri meleke kazanmalarını sağlamıştır. Üçüncü kısım, müçtehit fi'l-mezhep denilebilecek kimselerin taklididir. Bu kimseler usulde mezhep imamını taklit ederler ancak mesâilde müçtehittirler. Dördüncü kısım ise mutlak müçtehidin taklididir. Bu kimseler her ne kadar mutlak müçtehit olsalar dahi Kitap ve Sünnet'te sarih nassın olmadığ yerlerde, kimi zaman sahabe veya tabiînin görüşlerini kendi kişisel görüşlerine takdim ederler. Bu ise Ebû Hanife, İmam Malik ve İmam Şafiî’de görülen bir durumdur (s. 84).

Dihlevî'nin mutlak müçtehidin faaliyetine dair verdiği dört madde önem arz etmektedir. Bunları şu şekilde sıralamak mümkündür: a) Usul inşa etmek, b) Sünnet ve âsârı toplayarak bunların işletilmesi, c) Kendisinden önce cevabı verilmemiş fürû meselelere cevap vermesi d) Mezkûr şeylerin deva- 
mında dördüncü bir haslet olarak, bu kimsenin benimsemiş olduğu mezhebin "semadan kabul görmesi" de zikredilmektedir (s. 99). Müellif, Dihlevînin müntesip mutlak müçtehit hakkındaki ifadelerini yorumlamış, müntesip olan kimselerin mutlak müçtehide usulde muhalefet ettiklerini belirtmiştir. Fakat mürsel hadisin hüccet olup olmaması, isnatlardaki tercihler veya ravinin fakih olup olmaması gibi yerlerde taklit ettiğini söylemektedir (s. 99).

Müellifin, İbn Kemal Paşa'nın fukaha taksimine dair mülahazaları içerisinde özellikle Leknevî, Mercânî ve Dihlevî gibi isimlerin etkisi görülmektedir. Zira benzer eleştirel yaklaşım müellif tarafında da dile getirilmektedir (s. 102-106). İmameyn'in de müntesip mutlak müçtehit oldukları belirtilmiş, bunun sadece hocalarının üstün konumda olmaları nedeniyle onlara nisbet edildiği ifade edilmiștir (s. 96).

Hanefî fukahasının tabakâtını İbn Kemal Paşa'nın tasnifi üzerinden değerlendiren müellif, Şafiî fukaha tabakâtını ise İbn Salâh'ın tasnifi üzerinden değerlendirmiş, Mâlikî ve Hanbelî’lerde bu yönlü bir tasnifin bulunduğunu ancak açıkça ifade edilmediğini belirtmiştir (s. 112).

Hanefî mezhebinin fukaha tabakâtını ele alan müellif, daha sonra mezhebin mesâilinin tasnifine yer vermektedir. Mezhep mesâilinin sınıflandırılmasının teâruz esnasında müftünün râcih ve mercûh olan görüşlerini bilmesini ve ona göre tercihte bulunması gibi pratik faydasına işaret etmiștir. Mesâili meşhur "zâhirü'r-rivâye", "nâdirü'r-rivâye" ve "vâklât" taksim üzerinden vermiş ve bu kapsamdaki eserleri şerhleri ve ulemanın mahut kitaplar için yapmış oldukları öne çıkan açıklamalara değinmiştir. Müellif bu noktada İmam Muhammed'in "zâhirü'r-rivâye" eserleri içerisine, onun Muvattâ rivayeti, Kitâbü'l-âsâr'ı ve Kitâbü'l-hücce alâ ehli'l-Medine'sinin de katılması gerektiğini ileri sürmüştür (s. 139). Bu bölümün son kısmında ise Dihlevî'nin mesâili taksim ettiği dörtlü tasnif ve müftünün fetva verirken takip edeceği sıralama yer almıştır (s. 149).

İbn Abidîn'in Resmü'l-müftī sindeki kaideleri özetleyen müellif, bunları on bir asıl başlık altında ele alarak şerh etmiş ve önemli açıklamalarda bulunmuştur. Bilhassa mezhepteki muteber metinler ile ilgili açıklamaları dikkat çekmektedir. Devamındaki konu başlığında ise özellikle fetva verirken dört mezheple sınırlı kalma vurgusu öne çıarken, başka bir mezheple fetva vermenin şartını beş şey olarak belirtmiş ve bunlarla ilgili açılamalarda bulunmuştur (s. 204-207).

Ezmânın tegayyürüyle ahkamın tegayyürü ilkesine uzunca yer ayıran müellif, bu kısmı dört ana başlık altında ele almıştır. Hükümlerin değişmesini; illetin, adet ve örfün, zaruret veya umumü'l-belvânın son olarak sedd-i zerâi gibi nedenlerden dolayı tağyire uğradığını belirtmiş ve konu ile ilgili örnekler vermiştir (s. 240). Müellif hükümlere zaruret ve hacet arasındaki 
farka dair fıkıh kitaplarında ayrım olmadığını belirtmiş ve bu iki önemli durum arasındaki farkı kendi zaviyesinden açıklamaya çalışmıştır (s. 270). Adet ve örfü ele alırken amelî örfü altı başlıkta inceleyen müellif, ilgili başlıklar altında klasik kaynaklardan örnekler serdetmiş kimi zaman ise kendi tercihlerine yer vermiștir (s. 262). Sedd-i zerâi ile açıklamalarını günümüzle ilişskilendiren Osmânî, (s. 277) konuyla ilgili yaptığı taksimin Şatıbî̀nin tasnifiyle benzerlik gösterdiği göze çarpmaktadır (s. 275, 280).

İftâ ve iftâ metodu ile alakalı kısım kitabın sonunda yer almış ve bu bölümün başında müftü için fetva vermenin gerekli ve yasak olduğu vakitlere yer verilmiştir. Müftünün fetva vermekten imtina etmesi gereken sebepler dokuz başlık altında toplanmıştır. Bu kısımda fetvada hata eden müftünün bunu müsteftîye bildirmesinin gerekli olup olmadığı ayrıca fetvasındaki hatadan dolayı ortaya çıkan zararın tazmininde müftünün durumunun ele alındığı başlıklar önem arz etmektedir.

Fetva verirken müftünün kesinlikle câri olan örfü bilmesinin gerekliliğine değinen müellif, bu hususta İmam Muhammed'in uygulamalı örneğini nakleder. Bununla birlikte, özellikle müsteftînin gerçeği yansıtmayan, vakıaya uygun olmayan yanlış yönlendirme veya spekülasyona açık ifadelerle sorduğu sorularda dikkatli olunması gerektiğine işaret etmiş, bu şekilde verilecek fetvaların toplumda ne gibi olumsuz tesir oluşturacağı yine yaşanan örnek üzerinden verilmiștir (s. 304). Fetva âdâbı, müftünün fetva verirken ve yazarken, müsteftînin fetva isterken dikkat etmesi gereken kurallar klasik kaynaklardan nakledilmiştir.

Bir iki konu dışında (uçakta namaz ve hoparlör kullanılarak kılınan namaz gibi s. 309-310) ifta meselesinin teorik zeminde ve klasik kaynaklar ışığında ele alındığını söylemek mümkündür. Günümüz fetva sistemiyle bağlantısının olmaması eser için dile getirilmesi gereken başka bir konudur. Müellifin Pakistan müftüsü olarak görevi de göz önünde bulundurulduğunda, teori ve pratiğin nasıl olduğuna veya nasıl olması gerektiğine, ${ }^{1}$ klasik kaynaklardaki mevcut olan şeylerin uygulama imkanına, açılımına veya zorluğuna, alan uygulamalarından hareketle bu tarz eserlere girmesi gereken konu başlıklarına dair öneri ve tavsiyelerin bu eserde bulunması beklenirdi. Ayrıca uygulama açısından başarılı olan ülkelere, kurumlara, oluşturulması gereken kurulların lüzumuna, bu heyette yer alacak kimselerin şartlarına dair genel bir yaklaşımın oluşturulması da yine eserde beklenilen hususlar arasında zikredilebilir. Zira değişen fetva konseptinin bunları iktiza ettiğini görmemek mümkün değildir. Ayrıca bilgiye ulaşma imkanlarının farklılaştığı günümüzde bu durumun ortaya çıkardığı imkanlar ve problemlerin de bu tarz eserlerde işlenmesi gereken konular arasına girdiği bir gerçektir. ${ }^{2}$

1 Benzer bir örnek için bk. Orhan Çeker, "Iffta ve Bir Fetva Defteri Örneği", Selçuk Üniversitesi İlahiyat Fakültesi Dergisi, 6 (1996), 35-54.

2 Modern dönemdeki fetva sorunlarına dair bk. Ahmet Yaman, "Yeni Zamanlarda Fetvaya Ne Oldu? 
Eserin bu baskısında, kitap içerisindeki konular her ne kadar birbirleriyle ilişkili olsa da bap, fasıl ve benzeri üst başlıkların olmaması konular arası geçişlerde uyumsuzluğa neden olmaktadır. Fakat eserin farklı yayınevlerindeki baskılarında (Dâru'l-kalem gibi) bu durumun giderildiği görülmektedir. Eserde ismi geçen kimi fukahanın biyografilerine kısa şekilde değinileceği ifade edilse de (s. 6) birçok yerde yarım sayfayı aşan terâcim nakilleri kitabın hacmini bir hayli artırmıştır. Ayrıca esere yapılacak isim indeksinin okuyucu için daha pratik kullanım sağlayacağı ise muhakkaktır. 